\title{
Response of Different Potassium Application Rates on Growth, Yield, Carbohydrates and Protein Content of Mungbean (Vignaradiata L.)
}

\author{
Murindangabo Yves Theoneste ${ }^{1}$, Lai Wah $\mathrm{Oo}^{2}$, Tafadzwa Gloria Chiwasa ${ }^{3}$, Sang Chul Lee (PhD $)^{4}$ \\ ${ }^{1,2,3,4}$ Department of Food Security and Agricultural Development, College of Agriculture and Life Science, Kyungpook National \\ University, Daegu, South Korea
}

\begin{abstract}
The study was conducted at Kyungpook National University, College of Agriculture and Life Sciences experimental site, Daegu, South Korea from November 2017/2018.The research objectives were to investigate the response of different potassium applicationsrates on the growth and yield of mungbean in the greenhouse and outside and to find the best potassium application rate on mungbean for enhancing high production. The field experimental design was a randomized complete block design and each treatment had four replications. Mungbean (Vignaradiata $L$.) was grown under five levels of potassium $K_{I}(0 \mathrm{~g} / \mathrm{pot}), \mathrm{K}_{2}(0.13 \mathrm{~g} / \mathrm{pot}), \mathrm{K}_{3}(0.3 \mathrm{~g} / \mathrm{pot})$, $K_{4}(0.5 \mathrm{~g} / \mathrm{pot})$ and $K_{5}(0.63 \mathrm{~g} / \mathrm{pot})$. The results showed that different potassium fertilizer applications have significantly affected the growth and yield of mungbean both inside and outside of the greenhouse. The application of $K_{4}(0.5 \mathrm{~g} / \mathrm{pot})$ produced the maximum seed yield $(7.81 \mathrm{~g})$ inside the greenhouse and $(8.16 \mathrm{~g})$ outside. The lowest yield $(3.11 \mathrm{~g})$ and $(3.82 \mathrm{~g})$ were observed at $\mathrm{K}_{1}(0 \mathrm{~g} / \mathrm{pot})$ inside and outside of the greenhouse respectively. Total carbohydrates and total proteins content were significantly increased by increasing applications of potassium. It can be concluded that the application of $K_{4}(0.5 \mathrm{~g} / \mathrm{pot})$ have shown the best results and can be used to get the maximum growth and yield of mungbean both inside and outside of greenhouse conditions. The potassium application outside condition gave a significantly higher growth and seed yield than inside the greenhouse.
\end{abstract}

Keywords: potassium, growth and yield, Carbohydrate, proteins, mungbean

\section{Introduction}

The mungbean (Vignaradiata L.) is the major pulse crop and also known as green gram. It is under the family of Leguminosae and is grown as a drought tolerant cash and quick-maturing crop in most of the countries. Mungbean is a shot-season indeterminate small-seeded pulse crop. The crop is originated from India and have been widely cultivated in India since ancient times. It is the main source of high nutritive protein content and an important role for malnutrition people.It is widely grown for use as a human food and also commonly grown as fodder, the green manure and cover crop. It contains $51 \%$ carbohydrate, $25 \%$ protein, $4 \%$ mineral, $1.3 \%$ fat and $3 \%$ vitamins (Kaul,1982). It is often considered as meat substitutes especially for people who eat vegetables in lessdeveloped countries as protein supplement. Mungbean as a pulse and legume crop is a prime importance because of its excellent flavor, easy digestibility, well palatability, good market price as well as its capability for biological nitrogen fixation (Mandal et al., 2009).

As populations are increasing all over the world, one of the protein rich foods (mungbean) is needed to provide nutrient supplement crops for increasing world populations. Fertilizers play an important role to increase crop yields for demanding food. To meet demand for it, more fertilizer is required and in an improved nutrient balance. Many farmers grow mungbean without applying any fertilizers (potassium) in most of the developing countries. The pests and diseases are also very serious problems when potassium was insufficient in the plant. Being a legume crop, it requires less nitrogen but potassium is the vital nutrient to get its high yield. When farmers do not apply potassium fertilizer, mungbean productivity is quite low compared to its average production. The growth of mungbean can improve by using balanced amount of potassium.

Potassium plays a vital role as macronutrient in plant growth and sustainable crop production (Baligar et al., 2001).Potassium is fundamental to many metabolics through the activation of large number of enzymes required for chemical reactions. Potassium is not only to promote the translocation of newly synthesized photosynthates but has also a beneficial effect on the mobilization of other nutrients. Potassium is the third macronutrient requires for plant growth, after nitrogen and phosphorus (Abbas et al., 2011). The application of potassium is important for efficient photosynthesis and helps to retain water use efficiently at growth period (Garg et al., 2005). Potassiumcan regulate the stomata activity to prevent water loss during the drought (Waraich et al., 2011). Potassium is also required to protect plant diseases and pests (Arif et al., 2008) and increases the yield (Ali et al., 2010). Potassium acts as an important role for nodulation, carbohydrate transport, nitrogen fixation and incorporation of combined nitrogen into protein. Potassium can improve plant immunity, root growth and enhance drought tolerance and reduces lodging. Potassium is the fundamental nutrient for crop growth to improve plant health, crop quality and yield. The proper application of potassium fertilizer increases crop yield and improves its quality. So, this research effort aimed to remove the constraints for low productivity of mungbean. Considering the above facts, the objectives of this research were to evaluate the responses of different potassium application rates on growth and yield of mungbean and to find the best potassium application on mungbean for enhancing high production. 


\section{Materials and Methods}

The study was conducted at Kyungpook National University, College of Agriculture and Life Sciences experimental site, Daegu, South Korea from November2017/2018

\section{Experimental site}

The experimental field was located at between $35^{\circ} 53^{\prime} 41.3^{\prime \prime}$ $\mathrm{N}$ and $128^{\circ} 36^{\prime} 45.9^{\prime \prime}$ E. The experimental soil texture was clay loam with $\mathrm{pH}$ 5.8. The area of climate was humid subtropical climate. There were four seasons in Daegu such as spring, summer, fall and winter. The temperature range was $-16^{\circ} \mathrm{C}$ and $40^{\circ} \mathrm{C}$.

\section{Treatments application and Experimental design}

The experiment had five treatments in the greenhouse and outside conditions and each treatment had four replications by using Randomized Complete Block Design. Mungbean (Vignaradiata L.) was grown under five levels of potassium $\mathrm{K}_{1}(0 \mathrm{~g} / \mathrm{pot}), \mathrm{K}_{2}(0.13 \mathrm{~g} / \mathrm{pot}), \mathrm{K}_{3}(0.3 \mathrm{~g} / \mathrm{pot}), \mathrm{K}_{4}(0.5 \mathrm{~g} / \mathrm{pot})$ and $\mathrm{K}_{5}(0.6 \mathrm{~g} / \mathrm{pot})$ as $\mathrm{K}_{2} \mathrm{O}$.

Total 20 pots inside the greenhouse and 20 pots outside the greenhouse $(30 \mathrm{~cm})$ diameter were filled with $10 \mathrm{~kg}$ of clay loam soil for growing mungbean. Nitrogen and Phosphorous were applied as a urea and $\mathrm{P}_{2} \mathrm{O}_{5}$, and $\mathrm{K}_{2} \mathrm{O}$ was used as potassium fertilizer source. The fixed recommended rates of nitrogen $(0.54 \mathrm{~g} / \mathrm{pot})$ and phosphorous $(0.3 \mathrm{~g} / \mathrm{pot})$ and each of potassium treatments $(0 \mathrm{~g}, 0.13 \mathrm{~g}, 0.3 \mathrm{~g}, 0.5 \mathrm{~g}$ and $0.6 \mathrm{~g} / \mathrm{pot})$ were applied to each pot before one day of sowing. Mungbean seeds were soaked in water a few minutes and put the petridish for 5-6 hours before sowing. The pots were prepared randomly according to the planned layout. The three seeds were sown in one pot at the depth of $(1.5 \mathrm{~cm})$ on $24^{\text {th }}$ November,2017 inside the greenhouse and $1^{\text {st }}$ May, 2018 outside the greenhouse. All the required cultural and other management practices were the same inside the greenhouse and outside conditions. Thinning was done at 10 days after germination and only one plant was left in each pot. The water was applied to all pots uniformly every 3 days to keep adequate soil moisture. Plant protection managements were given to keep themungbean free from diseases and insects. Weeds were removed by hand throughout the growing season. Mungbean was harvested at fully maturity when the colour of pods were turned to dark brown. The crop was picked within 80-90days after sowing.

\section{Data Analysis}

All data recorded was entered into Microsoft Excel and Analysis of variance (ANOVA) was used to test treatment effects and where treatment effects were significant at $p<0.05$, means were separated using \pm standard error of the difference.

\section{Results and Discussions}

The experiment in the pots was carried out to determine the responses of the different potassium application rates on crop growth and yield of mungbean and the best potassium application on mungbean for enhancing maximum production. Different potassium application rates significantly affected the plant height, number of branches per plant, number of pods per plant, pod length, number of seeds per pod, seed weight, seed yield and nutrient content of mungbean as presented below.

\section{Effect on the plant height}

The plant height of mungbean was significantly affected due to different potassium application rates inside the greenhouse and outside. (Fig.1) showed the results of the plant height for each potassium treatments. In the greenhouse, the highest plant height $(20.75 \mathrm{~cm})$ was observed at $\mathrm{K}_{4}(0.5 \mathrm{~g} / \mathrm{pot})$ and followed by $(19.13 \mathrm{~cm}, 17.80 \mathrm{~cm}$ and $16.70 \mathrm{~cm})$ in $\mathrm{K}_{5}, \mathrm{~K}_{3}$ and $\mathrm{K}_{2}$ while the lowest plant height $(15.38 \mathrm{~cm})$ was observed in $\mathrm{K}_{1}$ treatment where potassium was not applied. Outside conditions, the highest plant height $(21.88 \mathrm{~cm})$ was observed at $\mathrm{K}_{4}(0.5 \mathrm{~g} / \mathrm{pot})$ and followed by $(20.75 \mathrm{~cm}, 19.13 \mathrm{~cm}, 18.63 \mathrm{~cm})$ in $\mathrm{K}_{5}, \mathrm{~K}_{3}$ and $\mathrm{K}_{2}$. The lowest plant height $(16.88 \mathrm{~cm})$ was observed in $\mathrm{K}_{1}$ treatment $(0 \mathrm{~g} / \mathrm{pot})$. This study showed that the plant height increased with increasing potassium levels up to $\mathrm{K}_{4}(0.5 \mathrm{~g} / \mathrm{pot})$ and then decreased gradually. The results were in agreements that the plant height was significant affected by different potash levels that could enhance the strength of the height and potassium fertilizer improved the height of plant,branches, pods, seed yield and seed weight (Fatima et al., 2001; Kumar et al., 2014; Jamil et al., 2018). In both conditions, the plant height in outside condition produced taller than in the greenhouse.

\section{Effect on number of branches per plant}

Different potassium application rates showed no significant variation in number of branches per plant inside the greenhouse and outside. (Fig.1) shows that the highest number of branches (6.25) was observed at $\mathrm{K}_{4}(0.5 \mathrm{~g} / \mathrm{pot})$, which was similar branches (6.25) at $\mathrm{K}_{5}$ compared with $\mathrm{K}_{1}$ where no potash was applied. $\mathrm{K}_{1}(0 \mathrm{~g} / \mathrm{pot})$ obtained the lowest number of branches (5.50) in the greenhouse. At outside conditions, the results showed that the highest number of branches per plant (6.50) was also at $\mathrm{K}_{4}$ $(0.5 \mathrm{~g} / \mathrm{pot}) . \mathrm{K}_{1}(0 \mathrm{~g} / \mathrm{pot})$ produced the lowest number of branches (5.75). But there were no statistical differences in number of branches among the treatments. This similar result also found by Asghar Ali et al., 2006.

\section{Effect on number of pods per plant}

The effect of different potassium application rates showed significant effect on the number of pods per plant of mungbean inside and outside of the greenhouse (Fig 2). Results showed that the highest pods per plant (20) was produced in $\mathrm{K}_{4}$ treatment which was statistically similar with $\mathrm{K}_{5}$ (19.50) and followed by $\mathrm{K}_{3}(17.75)$ and $\mathrm{K}_{2}$ (13.00). The lowest number of pods per plant (11.25) was produced at $\mathrm{K}_{1}$ $(0 \mathrm{~g} / \mathrm{pot})$ treatment using no potassium inside the greenhouse. In the outside case, the results showed that the highest pods per plant (21.00) was produced in $\mathrm{K}_{4}$ treatment which was statistically similar to $\mathrm{K}_{5}(20.50)$ and followed by $\mathrm{K}_{3}$ (18.50) and $\mathrm{K}_{2}$ (15.75) respectively. The lowest pods per plant (12.75) was produced in $\mathrm{K}_{1}$ treatment. The same result was reported that potassium application of $90 \mathrm{~kg} / \mathrm{ha}$ gave the maximum number of pods per plant on mungbean (Hussainet al., 2011). This result contradicted the findings of Asghar Ali et al., (2006) reported that potassium applications had non-significant differences in no. of pods/plant. In both conditions, this study showed that the 


\section{International Journal of Science and Research (IJSR) \\ ISSN: 2319-7064}

ResearchGate Impact Factor (2018): 0.28 | SJIF (2018): 7.426

number of pods in outside condition produced higher pods than in the greenhouse.

\section{Effect on pod length (cm)}

The data presented in (Fig.2) indicated that significant variation was observed on pod length inside the greenhouse and outside conditions. The longest pod length $(7.08 \mathrm{~cm})$ was obtained in $\mathrm{K}_{4}(0.5 \mathrm{~g} / \mathrm{pot})$ treatment, which was similar with $\mathrm{K}_{5}(6.98 \mathrm{~cm})$ and followed by $\mathrm{K}_{3}(6.03 \mathrm{~cm})$ and $\mathrm{K}_{2}(5.30 \mathrm{~cm})$ respectively. The shortest pod length $(5.05 \mathrm{~cm})$ was obtained at $\mathrm{K}_{1}(0 \mathrm{~g} / \mathrm{pot})$ treatment inside the greenhouse. Outside conditions, the results showed that the longest pod length $(7.28 \mathrm{~cm})$ was obtained in $\mathrm{K}_{4}(0.5 \mathrm{~g} / \mathrm{pot})$ treatment and followed by $K_{5}(7.10 \mathrm{~cm})$ and $K_{3}(6.30 \mathrm{~cm})$ and $K_{2}(5.58 \mathrm{~cm})$ respectively. The shortest pod length $(5.18 \mathrm{~cm})$ was obtained at $\mathrm{K}_{1}(0 \mathrm{~g} / \mathrm{pot})$ treatment where no potassium was applied. Among the treatments, $\mathrm{K}_{4}(0.5 \mathrm{~g} / \mathrm{pot})$ treatment produced the longest pod length in the greenhouse and outside. The same result found that the application of $25 \mathrm{~kg} \mathrm{~K} / \mathrm{ha}$ significantly observed the longest pod length (Mazedet al.,2015). In both conditions, the pod length in outside condition was taller than inside the greenhouse.

\section{Effect on number of seeds per pod}

The data on the number of seeds per pod as influenced by different potassium applications was presented in (Fig.3). The number of seeds per pod was the important parameter used to calculate mungbean yield. Results showed that $\mathrm{K}_{4}$ $(0.5 \mathrm{~g} / \mathrm{pot})$ treatment got the highest seeds per pod $(8.10)$ which was statistically similar with $\mathrm{K}_{5}(0.6 \mathrm{~g} / \mathrm{pot})(7.95)$ but different with other treatments. $K_{1}(0 \mathrm{~g} / \mathrm{pot})$ showed the lowest seeds per pod (5.69) where no potash was applied in the greenhouse. The outside case showed the highest seeds per pod (8.32) in $\mathrm{K}_{4}(0.5 \mathrm{~g} / \mathrm{pot})$ treatment, which was statistically similar with $\mathrm{K}_{5}(0.6 \mathrm{~g} / \mathrm{pot})(8.24)$ but different with other treatments. The lowest seeds per pod (5.89) was observed in $\mathrm{K}_{1}(0 \mathrm{~g} / \mathrm{pot})$ treatment. The proper potassium fertilizer rate increased the pods setting and leads to the highest seeds per pod. Among the treatments, $\mathrm{K}_{4}(0.5 \mathrm{~g} / \mathrm{pot})$ treatment produced the highest seeds per pod in the greenhouse and outside. In both conditions, the number of seeds per pod in the outside condition was higher than inside the greenhouse. These results also confirm that the number of seeds/pod was significantly increased due to potassium applications (Hussain et al., 2011; Kumar et al., 2014;Jamil et al., 2018). Potassium served as not only transporter of the other nutrients but also enhanced the photosynthesis rate to increase seed filling inside the pod of mungbean.

\section{Effect on (100) seed weight}

There was significant variation on (100) seed weight when different rates of potassium fertilizers were applied on mungbean shown in (Fig.3). Among the different potassium applications, the application of $\mathrm{K}_{4}(0.5 \mathrm{~g} / \mathrm{pot})$ produced the highest seed weight $(5.67 \mathrm{~g})$, which was statistically similar with $\mathrm{K}_{5}(5.48 \mathrm{~g})$ and followed by $\mathrm{K}_{3}(4.96 \mathrm{~g})$ and $\mathrm{K}_{2}(4.94 \mathrm{~g})$. The application of $\mathrm{K}_{1}(0 \mathrm{~g} / \mathrm{pot})$ treatment produced the lowest seed weight $(4.30 \mathrm{~g})$ in the greenhouse. The same results in outside condition recorded that the application of $\mathrm{K}_{4}$ $(0.5 \mathrm{~g} / \mathrm{pot})$ produced the highest seed weight $(5.92 \mathrm{~g})$ which was statistically similar with $\mathrm{K}_{5}(5.64 \mathrm{~g})$ and followed by $\mathrm{K}_{3}$ (5.28g) and $\mathrm{K}_{2}(5.26 \mathrm{~g})$. The application of $\mathrm{K}_{1}(0 \mathrm{~g} / \mathrm{pot})$ treatment produced the lowest seed weight (4.99g). Among all treatments, $\mathrm{K}_{4}(0.5 \mathrm{~g} / \mathrm{pot})$ treatment produced the heavier seed weight than other treatments. The same result also found by Hussain et al., (2011) who reported that 1000 seed weight of mungbean was increased at $90 \mathrm{~kg} \mathrm{~K}_{2} \mathrm{O} / \mathrm{ha}$ compared with other treatments. Potassium helped to increase grain filling and 100 seed weight on mungbean. In both conditions, the heavier seed weight was observed from the outside condition as compared to the greenhouse for each potassium treatment.

\section{Effect on the seed yield}

Different levels of potassium significantly influenced on the seed yield of mungbean (Fig.4). Seed yield was increased significantly with increased application ratesof potassium $\mathrm{K}_{4}$ $(0.5 \mathrm{~g} / \mathrm{pot})$. The maximum seed yield $(7.81 \mathrm{~g})$ was produced in the application of $\mathrm{K}_{4}(0.5 \mathrm{~g} / \mathrm{pot})$ followed by $\mathrm{K}_{5}(0.6 \mathrm{~g} / \mathrm{pot})$ $(7.35 \mathrm{~g}), \mathrm{K}_{3}(0.3 \mathrm{~g} / \mathrm{pot})(6.23 \mathrm{~g})$ and $\mathrm{K}_{2}(0.13 \mathrm{~g} / \mathrm{pot})(4.57 \mathrm{~g})$. The minimum seed yield $(3.11 \mathrm{~g})$ was produced in $\mathrm{K}_{1}$ $(0 \mathrm{~g} / \mathrm{pot})$ where no potassium was applied in the greenhouse. Outside showed that the maximum seed yield $(8.16 \mathrm{~g})$ was produced atK $4(0.5 \mathrm{~g} / \mathrm{pot})$ which was statistically similar with $\mathrm{K}_{5}(0.6 \mathrm{~g} / \mathrm{pot})(7.89 \mathrm{~g})$ and followed by $\mathrm{K}_{3}(0.3 \mathrm{~g} / \mathrm{pot})(6.58 \mathrm{~g})$ and $\mathrm{K}_{2}(0.13 \mathrm{~g} / \mathrm{pot})(5.46 \mathrm{~g})$ when the minimum seed yield $(3.82 \mathrm{~g})$ was produced in $\mathrm{K}_{1}(0 \mathrm{~g} / \mathrm{pot})$ where no potassium was applied. Among all treatments, $\mathrm{K}_{4}(0.5 \mathrm{~g} / \mathrm{pot})$ treatment produced more seed yield than other treatments. Seed yield in outside condition was produced higher yield than inside the greenhouse. Chaudhry and Mahmood (1999) also found that the application of $50 \mathrm{~kg} \mathrm{~K}_{2} \mathrm{O} /$ ha observed the maximum yield (832 kg/ha) in mungbean. Maliet al., (2001); Hussain et al., (2011); Buriro. M. et al., (2015)also agreed that the potassium applications increased significantly the seed yield of mungbean. Increasing seed yield obtained by increasing seed weight. Potassium helped for increasing number of pods, number of seeds/pod, seed weight that lead to increase seed yield.

\section{Effect on Harvest Index (\%)}

Data in (Fig.4) showed that there was significant variation in the harvest index of mungbean when different potassium application rates were applied inside the greenhouse and outside conditions. $\mathrm{K}_{1}(0 \mathrm{~g} / \mathrm{pot})$ treatment showed the highest harvest index $(52.69 \%)$ and $\mathrm{K}_{5}(0.6 \mathrm{~g} / \mathrm{pot})$ treatment showed the lowest harvest index $(50.91 \%)$ inside the greenhouse. In outside condition, $\mathrm{K}_{1}(0 \mathrm{~g} / \mathrm{pot})$ treatment observed the highest harvest index $(53.85 \%)$ among all treatments while $\mathrm{K}_{5}$ treatment $(0.6 \mathrm{~g} / \mathrm{pot})$ treatment showed the lowest harvest index $(51.88 \%)$. The same result found that potassium applications increased the harvest index of mungbean (Buriro. M. et al., 2015). Potassium increased the leaf area index and also increased the plant dry matter accumulation. Not only the seed yield but also the plant dry weight was high so the harvest index of mungbean had significant differences due to different potassium applications in this study. In both conditions, the harvest index in the outside condition was observed higher than in the greenhouse.

\section{Effect on total carbohydrate content}

Different potassium applications had a significant influence on total carbohydrate content of mungbean shown in (Fig 10). The highest total carbohydrate content (31.04) was observed in $\mathrm{K}_{5}(0.6 \mathrm{~g} / \mathrm{pot})$ treatment and followed by $\mathrm{K}_{4}$ (30.33), $\mathrm{K}_{3}$ (28.28) and $\mathrm{K}_{2}$ (27.37). The lowest total 


\section{International Journal of Science and Research (IJSR) \\ ISSN: 2319-7064}

ResearchGate Impact Factor (2018): 0.28 | SJIF (2018): 7.426

carbohydrate (26.04) was observed in $\mathrm{K}_{1}(0 \mathrm{~g} / \mathrm{pot})$ treatment in the greenhouse. In case of carbohydrate content, the order of the treatments was $\mathrm{K}_{5}, \mathrm{~K}_{4}, \mathrm{~K}_{3}, \mathrm{~K}_{2}$ and $\mathrm{K}_{1}$.

Outside condition, the highest total carbohydrate (31.53) was observed in $K_{5}(0.6 \mathrm{~g} / \mathrm{pot})$ treatment and followed by $\mathrm{K}_{4}$ (30.68), $\mathrm{K}_{3}$ (29.11) and $\mathrm{K}_{2}$ (28.58). The lowest total carbohydrate (27.19) was observed in $\mathrm{K}_{1}(0 \mathrm{~g} / \mathrm{pot})$ treatment. In case of carbohydrate content, the order of the treatments was $\mathrm{K}_{5}, \mathrm{~K}_{4}, \mathrm{~K}_{3}, \mathrm{~K}_{2}$ and $\mathrm{K}_{1}$ respectively. In both conditions, the outside experiment obtained higher total carbohydrate content than in the greenhouse.

\section{Effect on total protein content}

The results of the protein content of mungbean as affected by different potassium application rates were shown in (Fig5). $\mathrm{K}_{5}(0.6 \mathrm{~g} / \mathrm{pot})$ treatment obtained the highest total protein content $(25.35 \%)$ which was statistically similar with $\mathrm{K}_{4}(25.26 \%)$ and followed by $\mathrm{K}_{3}(24.51 \%)$ and $\mathrm{K}_{2}(24.33 \%)$ while $\mathrm{K}_{1}(0 \mathrm{~g} / \mathrm{pot})$ obtained the lowest total protein content $(23.81 \%)$ in the greenhouse.

Potassium also affected protein and carbohydrate synthesis in plants. The results in the outside condition found that $\mathrm{K}_{5}$ $(0.6 \mathrm{~g} / \mathrm{pot})$ treatment obtained the highest total protein content $(26.09 \%)$ which was statistically similar with $\mathrm{K}_{4}$ $(26.07 \%)$ and followed by $\mathrm{K}_{3}(25.06 \%)$ and $\mathrm{K}_{2}(24.77 \%) . \mathrm{K}_{1}$ $(0 \mathrm{~g} / \mathrm{pot})$ treatment obtained the lowest total protein content $(24.03 \%)$. In both conditions, total protein content in the outside condition gave higher amount than in the greenhouse.

Potassium could activate a large number of enzymes to induce the synthesis of protein and carbohydrates. Potassium helped to improve the uptake of available nitrogen from the soil and changed nitrogen to protein content in grain. Potassium helped to maintain a normal balance between carbohydrates and proteins. The different potassium applications significantly influenced on carbohydrate and protein content of mungbean. Similar results were recorded by Asghar Ali et al., (2006), Hussain et al., (2011), Biswash et al., (2014), Kumar et al., (2014) andRanpariyaet al., (2017) who reported that protein content of mungbean increased significantly with increasing levels of potassium.

\section{Conclusions}

The maximum growth and yield of mungbean produced with the increase application of potassium $\mathrm{K}_{4}(0.5 \mathrm{~g} / \mathrm{pot})$ in the greenhouse and outside. Total carbohydrate and total protein content were also significantly increased with increasing applications of potassium. Therefore, the application of potassium at $\mathrm{K}_{4}(0.5 \mathrm{~g} / \mathrm{pot})$ can perform as the best application rate of potassium for enhancing growth and seed yield of mungbean in both conditions. The potassium application in outside condition gave a significantly higher growth and seed yield than inside the greenhouse.

\section{References}

[1] Abbas G, Aslam M, Malik AU, Abbas Z, Ali M, Hussain F (2011). Potassium sulphate effects on growth and yield of mungbean (VignaradiataL.) under arid climate. Int. J. Agric. Appl. Sci. 3(2):72-75.

[2] Ali MA, Abbas GQ, Mohyuddin K, Ullah Abbas G, Aslam M (2010). Response of mungbean (Vignaradiata) to phosphatic fertilizer under arid climate.J. Anim. Plant Sci. 20(2):83-86.

[3] Arif M, Arshad M, Khalid A, Hannan A (2008). Differential response of rice genotypes at deficit and adequate potassium regimes under controlled conditions. Soil Environ. 27(1):52-57.

[4] Asgar Ali, Nadeem M.A, MuddassarMaqbool, Ejaz M (2006). Effect of different levels of potash on growth, yield and protein contents of mungbean varieties. J. Agric. Res. 44(2):121-126.

[5] Baligar V.C., Fageria N.K. and He Z.L. 2001. Nutrient use efficiency in plants.Communications in Soil Science and Plant Analysis. 32:921-950.

[6] Biswash, M. R.; M. W. Rahman, M. M. Haque, M. Sharmin, R. Barua.(2014). Effect of potassium and vermicompost on the growth, yield and nutrient contents of mungbean (BARI Mung 5). Open Science Journal of Bioscience and Bioengineering. 1(3): 33-39.

[7] Buriro, M., Hussain, F., Talpur, G. H., Gandahi, A. W., and Buriro, B. (2015). Growth and yield response of mungbean varieties to various potassium levels. Pak. $J$. Agri., Agril. Engg., Vet. Sci., 2015, 31 (2): 203-210.

[8] Chaudhry, A.U. and Mahmood, R. 1999. Determination of optimum level of potassium and its effect on yield and quality of three mungbean (VignaradiataL.) cultivars. Pak. J. Biol. Sci. 2(2): 449-451.

[9] Fatima, A. A., R. H. Fardoas and W. M. Rizk. 2001. Effect of potassium fertilization on mungbean (Vigna radiate L.) Wilczek, Egypt. J. Appl. Sci.,16: 156-167.

[10] Garg BK, Burmin U, Kathju S (2005). Physical aspects of drought tolerance cluster bean and strategies for yield improvement under arid conditions. J. Arid. Legumes 2:61-66.

[11]Hussain, F., Malik, A.U., Haji, M.A., Malghani, A.L., 2011. Growth and yield response of two cultivars of mungbean to different potassium levels. J.Anim.plant Sci. 21(3): 622-625.

[12] Jamil, M., Abbasi, G.H., Hussain, A., Malik, Z. and Sufyan, A., 2018. Response of mungbean to potassium application rates under desert climate. Park. J. Agri., Agril. Engg., Vet. Sci., 2018, 34 (1): 10-21.

[13] Kaul, A. K. (1982). Pulses in Bangladesh. BRAC, Farm Gate, Dhaka. p.27.

[14] Kumar, P., Kumar, P., Singh, T., Singh, A.K. and Yadav, R.A., 2014.Effect of different potassium levels on mungbean under custard apple based agri-horti system. African J. Agri.research.,9(8): 728-734.

[15] Mali, G.C., Sharma, N.N., Gupta, S.K. and Gupta, P.K. 2001.Response of mungbean to potassium and Sulphur fertilization on vertisols in humid agro-ecosystems in Rajasthan.Potassium Nut.Ann. Crops: 246-249.

[16] Mandal, S., M. Mandal and A. Das. 2009. Stimulation of indole acetic acid production in a Rhizobium isolate of Vignamungoby root nodule phenolic acids. Arch. Microbiol., 191: 389- 393.

[17] Mazed, H. E. M. K., Moonmoon, J.F., Md. NazmulHaque, Md. Ashraful Islam Pulok and Md. HafizurRahman (2015).Growth and yield of Mungbean 


\section{International Journal of Science and Research (IJSR) \\ ISSN: 2319-7064}

ResearchGate Impact Factor (2018): 0.28 | SJIF (2018): 7.426

as influenced by potassium and Sulphur. Annals of Biological Research, 2015, 6 (1):6-10.

[18] Ranpariya, V.S., Polara, K.B., Savaliya, C.M., Modhvadiya, V.L. and Bodar, K.H. (2017).Effect of potassium, zinc and FYM on growth, quality and yield of summer green gram (Vignaradiata L.) under medium black calcareous soil.International Journal of Science,
Environment and Technology, Vol. 6, No 4, 2017, 2242 $-2247$.

[19] Waraich EA, Ahmad R, Saifullah M. Ashraf Y, Ehsanullah E (2011). Role of mineral nutrition in alleviation of drought stress in plants. Aust. J. Crop Sci.5:764-777.

\section{Response of different potassium applications on growth and yield of mungbean (Vignaradiata $\mathrm{L}$.)}
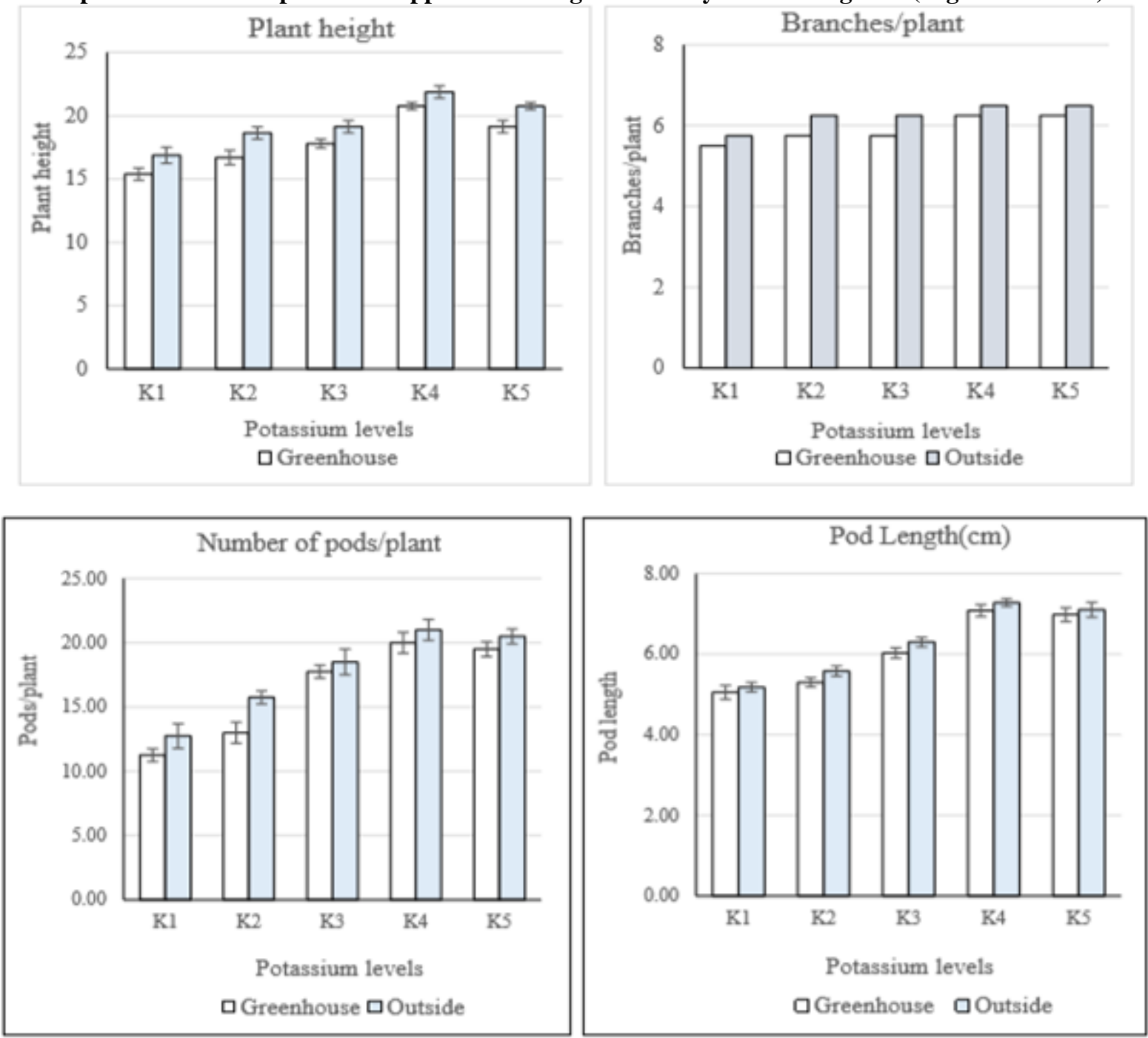

Fig 2. Comparison of the number of pods per plant and pod length on mungbean at different potassium applications in the greenhouse and outside 
International Journal of Science and Research (IJSR)

ISSN: 2319-7064

ResearchGate Impact Factor (2018): 0.28 | SJIF (2018): 7.426
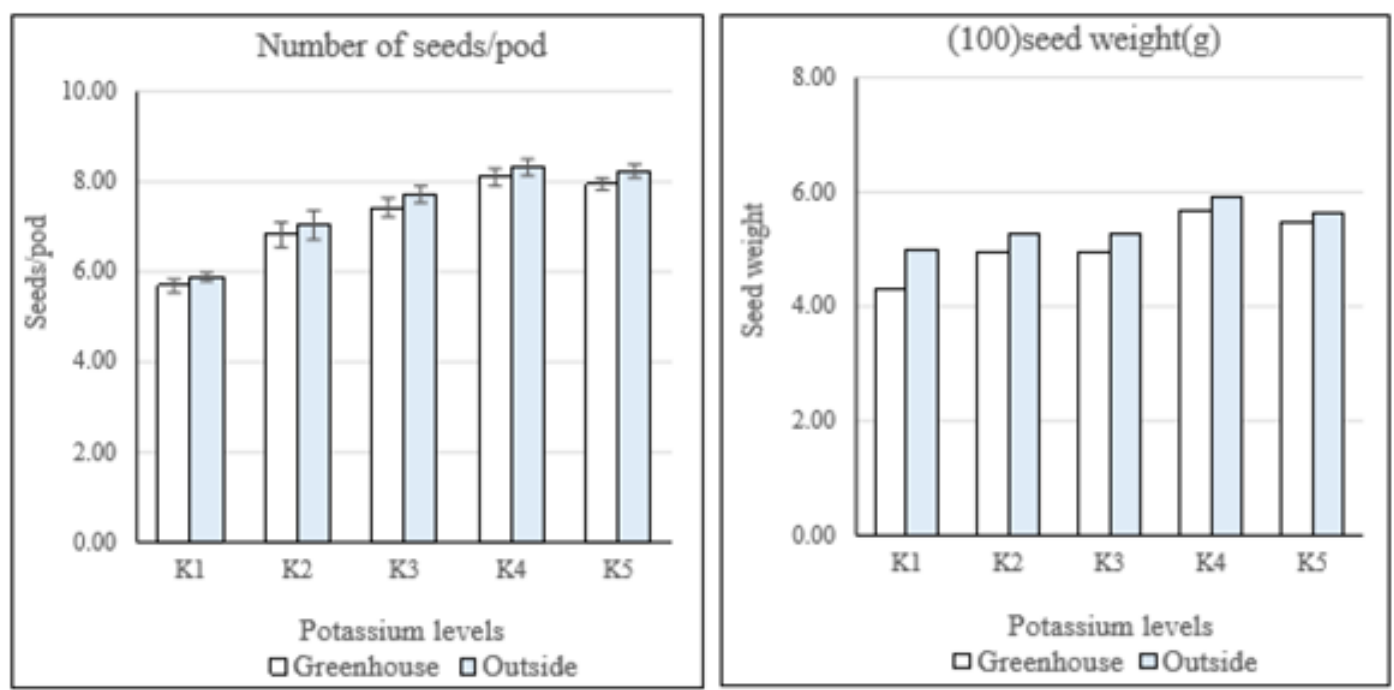

Fig 3. Comparison of the number of seeds per pod and (100) seed weight on mungbean at different potassium applications in the greenhouse and outside
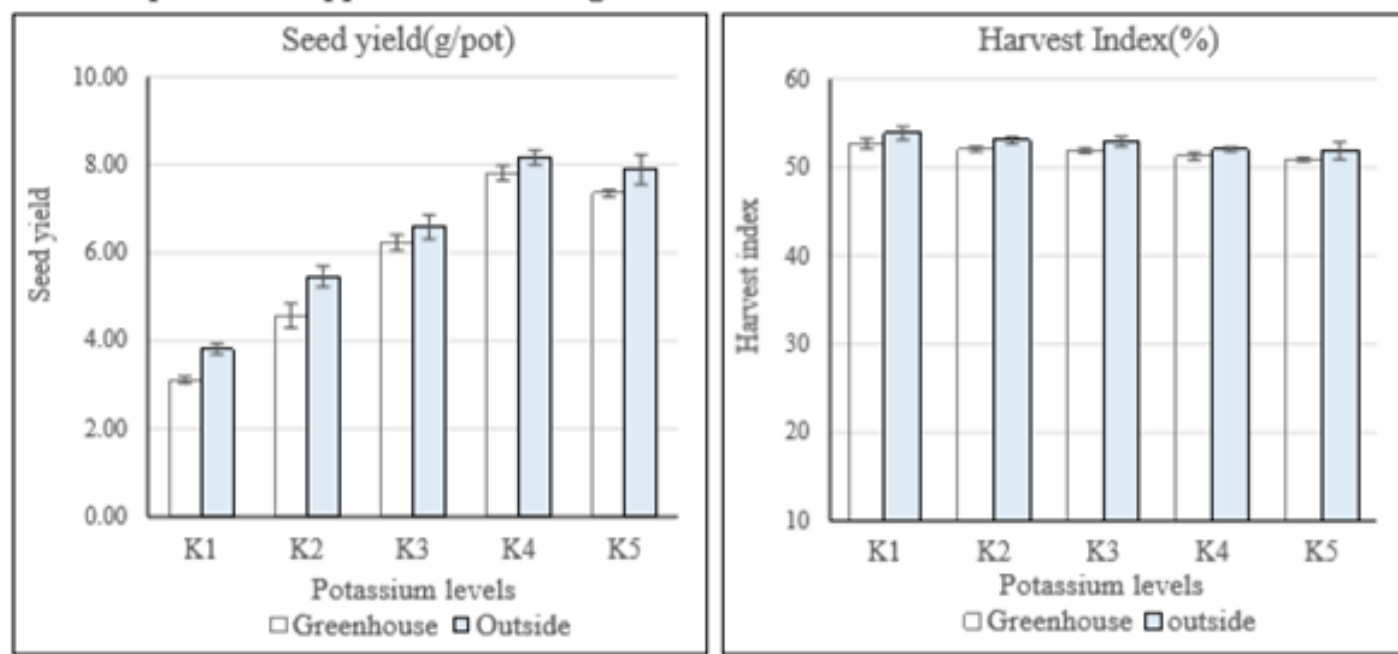

Fig 4. Comparison of seed yield and harvest index (\%) on mungbean at different potassium applications in the greenhouse and outside
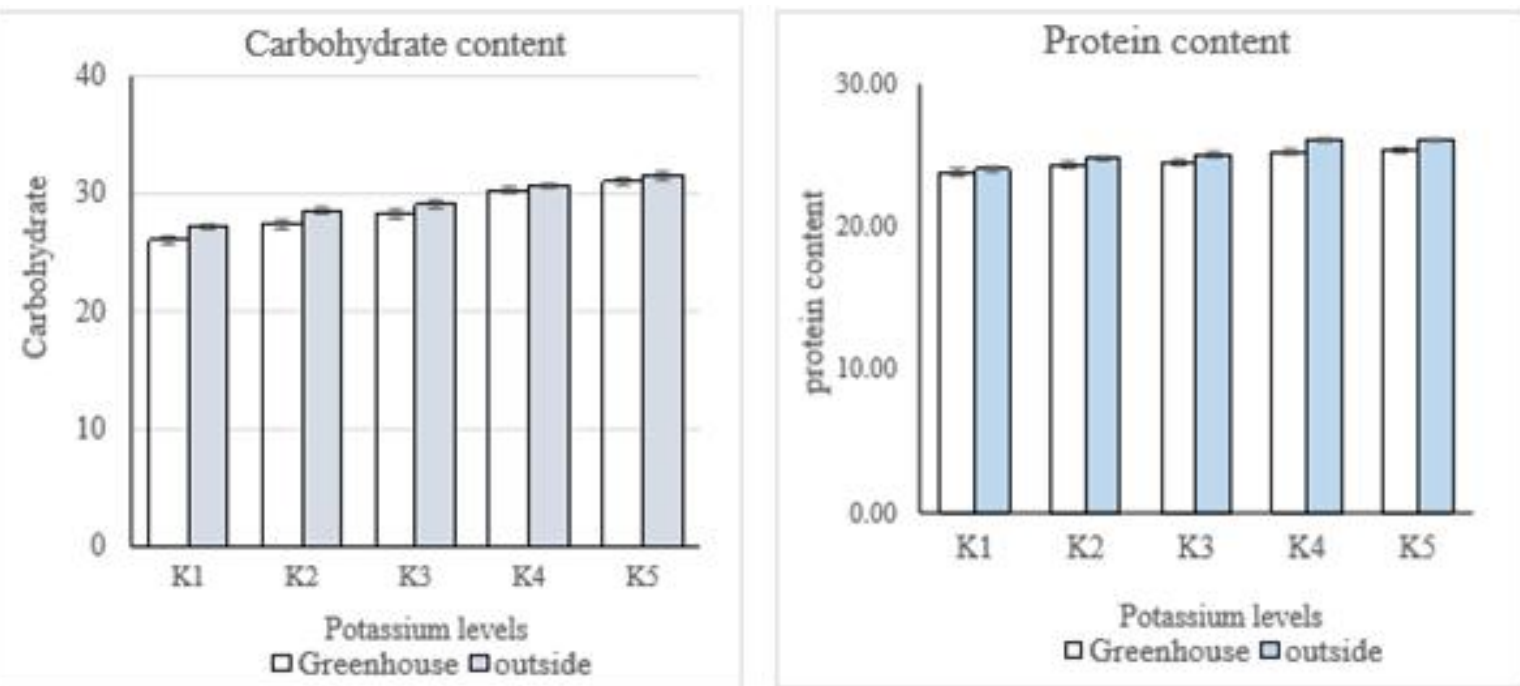

Fig 5. Comparison of total carbohydrate and total protein content on mungbean at different potassium applications in the greenhouse and outside

Volume 8 Issue 8, August 2019

www.ijsr.net

Licensed Under Creative Commons Attribution CC BY 